\title{
Tax evasion in Nepal: An Inquiry
}

\author{
Jit Bahadur K.C. \\ Associate Professor, Nepal Commerce Campus
}

\begin{abstract}
Purpose: This article analyses the degree of relationship between tax evasion, total tax revenue and economic growth in Nepal.

Methodology: This empirical study adopts secondary data from various journals, books, reports, booklets, and the websites in order to obtain objective results between the research variables (i.e., tax evasion, total tax revenue and economic growth) applying both research tools of correlation and linear regression analysis.

Findings: The study found an inverse relationship between the variables (i.e., tax evasion and total tax revenue (-0.678) and tax evasion and economic growth (-0.666)) under correlation analysis. Similarly, it found negative influence of the tax evasion on total tax revenue and economic growth under the regression analysis. The examination of the influence of tax evasion on the total tax revenue showed that, other elements of the taxes kept constant, an increase in tax evasion by 1 unit led to a decrease in value of tax revenue by 34.037. In the same way, study of the influence of the tax evasion on the economic growth (at current price) showed that, other things being constant, an increase in tax evasion by 1 unit led to a decrease in the economic growth by the value of 147.440. Thus, tax evasion has an inverse relationship with economic growth, and tax revenue.
\end{abstract}

Originality: This paper provides an explicit new result on association and influence between and on the research variables (i.e., tax evasion between and on the total tax and economic growth) in Nepal for the duration of 9 years. Thus, this study furnishes the new knowledge in the literature of the research variables.

Keywords: Taxation, tax burden, tax reduction, tax evasion, economic growth.

\section{Introduction}

Two origins remained notable in the course of human civilization, which oppose each other (e.g., scientists invented medicine to cure diseases, but these days, the same is now misused in various ways). Medicine is just a representative example of the abuse of inventions; there are countless more cases of abuse of inventions, both knowingly and unknowingly, in our society. It may be concluded that there are both positive and negative consequences of innovation

The evolution of taxation was and is for the civilized society because there are five reasons for its imposition: (a) raising revenue, (b) re-pricing of the goods and services, (c) redistribution of income and wealth, (d) representation and (e) reorganization of the economy. To attempt the stated purposes and to perform the functions of government, the leading scholars of public finance invented the principles of the taxation. As per its 
principles, a government imposes tax to perform the two major functions: protective (i.e., to protect life, liberty, and property of the citizens) and affirmative (i.e., to foster moral, ideological, or utilitarian goals) functions in the states without direct quid pro quo. However, the theories and principles of taxation are violated by both recipients and payers originating the two most popular evils: tax evasion and avoidance. The evidence supports that these evils are not new innovations; they are probably as old as taxation itself.

Evidently, there are three tax reduction techniques: (a) tax evasion, (b) tax avoidance and (c) tax planning. The former two techniques are the evils of the tax system. Burg (2004) claimed that tax evasion is an unlawful method of tax reduction to be paid and such practice of the evasion was emerged in the Han Dynasty of China while the tax avoidance came into the economy from the second half of the fourth century.

Experts believe that there is a considerable difference between the tax evasion and avoidance, but both are illegal in most of the countries. For example, McCann (2006) argued, "Evasion of tax is a crime in most countries because it amounts to defrauding the exchequer of money that is rightly due to it. Avoiding tax means using whatever strategies are available to ensure that one pays no more tax than the law requires" (p. 86). Sharma and Dang (2011) opined that the difference between tax evasion and tax avoidance is as thick as a prison wall. However, tax avoidance is legal in some countries; for example, it is legal in India, but illegal in most of the other countries in the world. Some leading scholars believe that the tax avoidance is also a crime. For example, Xuereb (2015) asserted that the tax avoidance refers reduction of tax liability by planning the affairs to bring the least tax possible all while acting within the provisions of the Acts. It is illegal as it minimizes the tax to be paid by utilizing the existing loopholes of the provisions of the Acts.

Out of the three techniques of tax reduction stated above, the tax evasion is illegal entire in the world; the tax avoidance is illegal in some countries and legal in others. In the context of Nepal, only tax planning is legal to minimize the tax liability as provided by tax law. Fundamentally, these activities significantly differ from each other in theory and practice.

Scholars suggest that both tax evasion and avoidance are harmful in all respects to the prosperity of the government and economic growth (i.e., gross domestic product (GDP)) of a nation. Therefore, tax evasion and avoidance are two evils for the entire human civilization. In other words, tax evasion is both illegal and unethical, not only does it decrease government revenue, but also hinders the overall development. It is an act of concealing taxes, through the submission of false documents, false statements or unrealistic information. According to the Income Tax Act of Nepal, tax evasion is punishable by charging a penalty equal to the difference between the accrued amount and the actual amount.

However, in spite of the penalty, tax evasion is increasing in trend in Nepal. Thus, we tried to inquire the degree of relationship between the tax evasion and the total tax revenue and the economic growth in this writing.

\subsection{Problems and issues}

Tax evasion includes both bitter and pleasant experience in the world. A leading 
economist of the 19th century, McCulloch (1863) pointed out that the political abuse and tax evasion in France were the major causes behind the industrial revolution.

Taxation is a primary tool to raise the revenue as required by the government to fund its public spending. However, there is a low tax to GDP ratio, not only in Nepal, but in the other developing countries as well. Because of this, developing countries face shortage of resources to fund even the essential activities. The experts of public finance believe that the reduction of the tax evasion and its success depends upon the cooperation to each other between the tax administration and taxpayers. Nepal, being one of the least developed countries in the world itself, is not an exception in this respect. For example, Nepali Times (2002) claimed that the then Joint Secretary of the Revenue Department of the Finance Ministry of Nepal, Bhoj Raj Ghimire said, "Tax evasion is a part of Nepali culture". Thus, almost taxpayers culturally motivated to pay fewer taxes. In the same way, Gyawali (2017) stated that the institutional corruption from the Commission for the Tax Clearance of Nepal, 2071. In addition, TeliaSonera (a non-resident company) sold its entire shares to Axiata (a non-resident company) in December of 2015, without paying capital gains tax to the Government of Nepal, evading about 33 billion rupees of tax.

The World Bank (2016) reported that Nepal ranks at 107 on the doing business comparison report in 2017, it ranked 99 in 2016. The report claims, "The main reasons behind the drop are a decline in Nepal's business, regulatory environment and data revisions". Even so, the ranking of Nepal remained second after Bhutan (73) and before Sri Lanka (110).

The Kathmandu Post (2017) and Trading Economics (2017) reported that, as per the corruption perception index of Transparency International, Nepal ranked 131 corrupted out of 175 countries in 2016.

Nalishebo and Halwampa (2014) claimed that there are various elements which lead to increase tax gap in an economy. The study enumerated seven elements which increase the tax gaps in the collection of taxes.

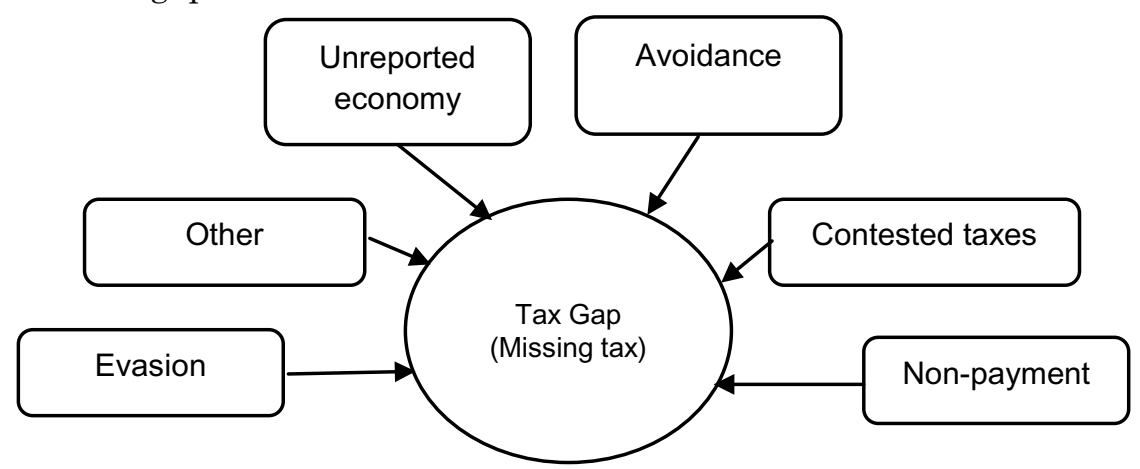

Figure 1: Elements of tax gap adapted from Nalishebo and Halwampa (2014, p. 21)

The stated facts prove that the status of the tax evasion in Nepal is in the significant amount because tax evasion exists pervasively, but there is no existence any research in this sector. Thus, we tried to inquire status of the tax evasion, its relationship, and impact on the total tax and economic growth 


\subsection{Objectives}

The primary objective of this study is to inquire the association and influence between on the research variables (i.e., association between the tax evasion, total tax revenue and economic growth, and the impact of the tax evasion on total tax revenue and economic growth). The secondary objectives are:

- To examine the association between the variables (tax evasion, total tax revenue generation and economic growth) in Nepal, and

- To evaluate the influence of tax evasion on total tax revenue and economic growth.

\subsection{Research hypothesis}

As to the objectives and research questions, we tested the following hypotheses:

- $H_{0}$ : There is no significant association between tax evasion, total tax revenue and economic growth in Nepal.

- $H_{0}$ : There is no significant influence of tax evasion on total tax revenue and economic growth in Nepal.

\subsection{Significance and delimitations}

We claimed that this empirical study on the inquiry on the tax evasion is useful for the policymakers, government officials, scholars, researchers, university teachers, students, examiners, examinees and other persons who desire to know about taxation and its evasion in Nepal. However, it includes some limitations: (a) it was written within the short time frame, (b) it covers the tax evasion data, total tax revenue and GDP at current price for the duration 9 years (since FY 2007-08 to 2015-16), and it excludes the tax evasion revenue raised by the Commission for the Investigation of Abuse of Authority (CIAA), (c) it only includes the tax evasion data from income tax and VAT, (d) the reliability of data of the tax evasion depends on the annual reports of the Inland Revenue Department (IRD).

\section{Literature review}

This section of the study is a succinct version of the previous research and studied; and highlighted a description, summary and evaluation of each source of review. Therefore, we analysed and presented the literature about the tax evasion, including other influencing factors like psychology, structuring the tax system, structuring statement by the taxpayers, non-compliance rate and bribery.

Table 1 Summary of the previous studies

\begin{tabular}{ll}
\hline Source & Findings, conclusion and suggestions \\
\hline Friedland, Maital, and & A large amount of fine and high tax rate stimulate the tax \\
Rutenberg (1978) & evasion and consequently taxpayers underreport their income. \\
Hasseldine and Bebbington & The government should consider economic and psychological \\
(1991) & aspects to reduce the tax evasion. \\
Murray (1997) & The change in tax structure cannot eliminate the avoidance and \\
Simser (2008) & evasion. The expansion of the tax base reduces the tax evasion. \\
\hline
\end{tabular}




Source Findings, conclusion and suggestions

In most cases, the gender, age, nationality, education,

Devos (2005) occupation and income level hold significant relationships with the incidence of tax evasion.

Barth, Cappelen and Ogneda Individuals with low wages, long working hours and unfair (2006)

Slemrod (2007) treatment stimulate a high rate of the tax evasion. $14 \%$ non-compliance rate of the federal tax of the United States with heterogeneity of the tax evasion.

Complicated income tax law, changing constantly and

Haloush (2008) ineffective government operations enhance tax evasion. The simple tax law and use to a variety of non-legal techniques controls the tax evasion.

Joulfaian (2009) The business noncompliance rises with the frequent tax related Uadiale, Fagbemi and Ogunleye (2010) bribes.

There is a positive relationship between personal income tax rates and tax evasion in Nigeria

There is a positive relationship between the tax evasion, the tax

Tabandeh, Jusoh, Nor, and

Zaidi (2012) burdens, the size of governments and inflation, while negative relationship between the taxpayers' income and trade openness with tax evasion

Bekoe (2012) The tax evasion is the single most important factor that holds the economic growth back.

Dalu, Maposa, Pabwaungana Loopholes in the tax system, corruption and bribery of the tax and Dalu (2012)

Adebisi and Gbegi (2013) officials through tax agent are the major problems.

There is a positive relationship between tax avoidance, tax evasion and tax rates on personal income tax in Nigeria.

Xuereb (2015) Narrow tax net increases the tax evasion and government needs to expand the tax net.

Zsombor, Simonovits and The U-shaped relationship between tax rates and tax evasion Vincze (2012); Mehrara and Farahani (2016) and concluded that higher tax rates induce more tax evasion and economic instability

Ahmad, Sial and Ahmad (2016) Significant negative effect between total tax revenue and economic growth in long run. If $1 \%$ increase in total tax that decreases GP by $1.25 \%$.

Bethencourt and Kunze (2016) A higher tax rate increases aggregate evasion and the number of evaders in the economy.

Gillman and Kejak (n.d.) The tax evasion decreases both tax revenue and economic growth.

\section{Sources: Author's compilation}

The survey of literature showed that the tax evasion hinders the tax revenues, economic growth and creates instability in the society. The study about tax evasion is an entire gap in the Nepalese literature. Thus, we tried to inquire the tax evasion in Nepal to add new knowledge. 


\section{Methodology}

Research methodology concerns overall research process from philosophical and theoretical part of the collection and analysis of data. To obtain the ontology of the association between and influence on the tax evasion on total tax revenue and GDP, we used deductive approach, mono-methods of quantitative research, survey strategy and obtained the secondary data from primary sources. The quantitative methods normally hold optimistic assumptions, they are based on the objective reality (i.e., facts are facts) obtained from the mathematical treatment.

We applied the time series data of the nine years (i.e., since the FY 2007/08 to 2015/16) to obtain the fact between the variables and the influence of the tax evasion on total tax revenue and GDP at current price. For this purpose, we collected data from Economic Survey, publication of Central Bureau of Statistics, Journals, Annual Reports of IRD (2008-2016), books, reports, and the internet.

We chose two analyses: correlation and regression. To test the overstate association between the variables, we used Karl Pearson's correlation coefficient and to test the influence of tax evasion on total tax revenue and GDP, we used simple linear regression.

In order to test the degree of association between the tax evasion and total tax revenue, we applied the following equations to test the tax evasion and economic growth.

$$
r=\frac{N \Sigma X Y-(\Sigma X)(\Sigma Y)}{\sqrt{N \Sigma X^{2}-(\Sigma X)^{2} \times} \sqrt{N \Sigma Y^{2}-(\Sigma Y)^{2}}}
$$

Correspondingly,

$$
r=\frac{N \Sigma T E . T T R-(\Sigma T E)(\Sigma T T R)}{\sqrt{N \Sigma T E^{2}-(\Sigma T E)^{2} \times} \sqrt{N \Sigma T T R^{2}-(\Sigma T T R)^{2}}} \quad \ldots \quad \ldots
$$

Where, $r=$ Correlation coefficient

$T E=$ Tax evasion,

$T T R=$ Total tax revenue, and

$N=$ Number of observations

$$
r=\frac{N \Sigma T E G D P-(\Sigma T E)(. \Sigma G D P)}{\sqrt{N \Sigma T E^{2}-(\Sigma T E)^{2} \times} \sqrt{N \Sigma G D P^{2}-(\Sigma G D P)^{2}}} \quad \ldots \quad \ldots
$$

Where,

$T E=$ Tax evasion,

$G D P=$ Gross domestic product (at current price), and

$N=$ Number of observations

We also chose to test the influence of the tax evasion with the total tax revenue and GDP. For this purpose, we applied the regression analysis between the variables. Thus, total tax revenue and GDP are the dependent variables while the tax evasion is the independent variable. To observe the influence of the tax evasion we employed linear regression. Thus, the functional forms of the model used were as specified below: 
$T T R=f(T E) \ldots \quad \ldots \quad \ldots \quad \ldots \quad \ldots$

Where,

$T T R=$ Total tax revenue (response variable) and

$T E=$ Tax evasion

Accordingly,

$T T R=\alpha+\beta_{1} T E_{i}+v_{\ldots} \quad \ldots \quad \ldots$

Where,

$\alpha=$ Intercept term (parameter),

$\beta_{1}=$ Parameter known as regression coefficient,

$U=$ Error Term or unexplained variables (residuals).

In another case, to evaluate the influence of tax evasion on the GDP, we employed the following equation of linear regression:

$G D P=f(T E) \ldots \quad \ldots \quad \ldots \quad \ldots$

Where,

$G D P=$ Gross domestic product (at current price)

$T E=$ Tax evasion

Accordingly, we specify:

$G D P=\alpha+\beta_{1} T E_{i}+v_{\ldots} \ldots \quad \ldots \quad \ldots$

Where,

$\alpha=$ Intercept term (parameter),

$\beta_{1}=$ Parameter known as regression coefficient,

$U=$ Error Term or unexplained variables.

\section{Results}

This main section is a part of the study and concerns the presentation of data, which were collected from different sources. According to the research questions and assumptions of the hypotheses, we divided this section into two parts: to test the relationship between the variables and to test the influence of the tax evasion on total tax revenue and economic growth.

\subsection{The degree of relationship of tax evasion with total tax revenue and economic growth}

The coefficient of correlation overstates the degree of relationship. For this purpose, we use simple correlation analysis between the tax evasion and total tax revenue and tax evasion and economic growth.

Table 2 Association between TE and TTR

\begin{tabular}{llcc}
\hline & TE & TTR \\
\hline \multirow{2}{*}{ TE Pearson Correlation } & 1 & $-.678^{*}$ \\
& Sig. (2-tailed) & & .045 \\
& N & 9 & 9 \\
Pearson Correlation & $-.678^{*}$ & 1 \\
TTR Sig. (2-tailed) & .045 & \\
$\quad$ N & 9 & 9 \\
\hline
\end{tabular}

*. Correlation is significant at the 0.05 level (2-tailed)
Table 3 Association between TE and GDP

\begin{tabular}{llcc}
\hline & TE & GDP \\
\hline \multirow{2}{*}{ TE } & Pearson Correlation & 1 & -.666 \\
& Sig. (2-tailed) & & .050 \\
& $\mathrm{~N}$ & 9 & 9 \\
Pearson Correlation & -.666 & 1 \\
GDP Sig. (2-tailed) & .050 & \\
$\mathrm{~N}$ & 9 & 9 \\
\hline
\end{tabular}


As shown in the table above, the association between tax evasion and total tax revenue and tax evasion and economic growth were 0.678 and -0.666 respectively, indicating a strong negative association between the tax evasion and total tax revenue and tax evasion and economic growth. It means that an increase in the value of tax evasion leads to a strong decrease in the value of total tax revenue and economic growth in Nepal. Thus, result suggested that not to accept the null hypothesis.

\subsection{Influence of tax evasion on total tax revenue}

First, we used linear regression model to examine the influence of the tax evasion on the total tax revenue. The following table highlights the model summary of the tax evasion on total tax revenue.

Table 4 Model summary of the influence of the tax evasion on the total tax revenue

\begin{tabular}{|c|c|c|c|c|c|c|c|c|}
\hline \multirow[b]{2}{*}{ Model } & \multirow[b]{2}{*}{$\mathrm{R}$} & \multirow[b]{2}{*}{ R Square } & \multirow[b]{2}{*}{$\begin{array}{l}\text { Adjusted R } \\
\text { Square }\end{array}$} & \multirow[b]{2}{*}{$\begin{array}{l}\text { Std. Error of } \\
\text { the Estimate }\end{array}$} & \multicolumn{3}{|c|}{ Change Statistics } & \multirow[b]{2}{*}{$\begin{array}{l}\text { Durbin- } \\
\text { Watson }\end{array}$} \\
\hline & & & & & $\begin{array}{cc}\text { R Square } & F \\
\text { Change } & \text { Change }\end{array}$ & $\mathrm{df} 1 \mathrm{df} 2$ & $\begin{array}{c}\text { Sig. F } \\
\text { Change }\end{array}$ & \\
\hline 1 & .678 & .459 & .382 & 8962.9533011 & $.459 \quad 5.943$ & 7 & .045 & .957 \\
\hline
\end{tabular}

a. Predictors: (Constant), TE

b. Dependent Variable: TTR

Fundamentally, $\mathrm{R}^{2}$ ( $\mathrm{R}$ squared) value measures the percentage of variation in the values of the dependent variable that can be explained by the variation in the independent variables and it varies from 0 to 1 . Thus, a value of 0.459 means that $45.90 \%$ variance of the dependent variable (i.e., total tax revenue) can be explained by the independent variable (i.e., tax evasion) and the balance of $54.10 \%$ can be explained by other variables (residuals) not included here. According to the model summary, the $\mathrm{R}$-squared value stood at $45.90 \%$. Statistically, an $\mathrm{R}$-squared value more than $60 \%$ is considered nicely fitted to explain the dependent variable. Similarly, the value of Durbin-Watson test stood close to one, (i.e., 0.957) which positively auto-correlated (i.e., far from the data element). It means that, to some extent, the error terms are dependent on each other.

In the same way, in the following table, we produced the result of regression coefficient to discuss the influence of the tax evasion on the total tax revenue.

Table 5 Coefficients of the influence of the tax evasion on the total tax revenue

\begin{tabular}{|c|c|c|c|c|c|c|c|c|}
\hline & \multirow[t]{2}{*}{ Model } & \multicolumn{2}{|c|}{$\begin{array}{l}\text { Unstandardized } \\
\text { Coefficients }\end{array}$} & \multirow{2}{*}{$\begin{array}{c}\text { Standardized } \\
\text { Coefficients } \\
\text { Beta }\end{array}$} & \multirow[t]{2}{*}{$t$} & \multirow[t]{2}{*}{ Sig. } & \multicolumn{2}{|c|}{$\begin{array}{c}95.0 \% \text { Confidence Interval } \\
\text { for B } \\
\end{array}$} \\
\hline & & B & Std. Error & & & & Lower Bound & Upper Bound \\
\hline \multirow{2}{*}{1} & (Constant) & 36047.207 & 5988.542 & & 6.019 & .001 & 21886.556 & 50207.859 \\
\hline & $\mathrm{TE}$ & -34.037 & 13.962 & -.678 & -2.438 & .045 & -67.053 & -1.021 \\
\hline
\end{tabular}

a. Dependent Variable: TTR

According to the stated figure, there is a significant negative relationship between tax evasion and total tax revenue. The empirical result showed that, other things remaining the same, an increase in the value of tax evasion by 1 -unit leads to a decrease in the value of total tax revenue by 34.037. Conclusively, there is a negative 
influence of the tax evasion on the total tax revenue. Thus, considering only the p-value, the results suggested rejecting the null hypothesis.

\subsection{Influence of tax evasion on economic growth}

The influence of tax evasion on economic growth is another analysis. Therefore, we fitted linear regression model to test the influence of the tax evasion on the economic growth.

Table 6 Model summary of the influence of the tax evasion on the GDP (current price)

\begin{tabular}{|c|c|c|c|c|c|c|c|c|c|c|}
\hline \multirow[b]{2}{*}{ Model } & & \multirow[b]{2}{*}{$\begin{array}{c}\mathrm{R} \\
\text { Square }\end{array}$} & \multirow[b]{2}{*}{$\begin{array}{l}\text { Adjusted } \\
\text { R Square }\end{array}$} & \multirow[b]{2}{*}{$\begin{array}{l}\text { Std. Error of } \\
\text { the Estimate }\end{array}$} & \multicolumn{5}{|c|}{ Change Statistics } & \multirow[b]{2}{*}{$\begin{array}{l}\text { Durbin- } \\
\text { Watson }\end{array}$} \\
\hline & & & & & $\begin{array}{c}\text { R Square } \\
\text { Change }\end{array}$ & $\begin{array}{c}\mathrm{F} \\
\text { Change }\end{array}$ & $\mathrm{df} 1$ & $\mathrm{df} 2$ & $\begin{array}{c}\text { Sig. F } \\
\text { Change }\end{array}$ & \\
\hline 1 & $66 \mathrm{a}$ & 444 & & 967 & .444 & 5.581 & 1 & 7 & .050 & .939 \\
\hline
\end{tabular}

a. Predictors: (Constant), TE

b. Dependent Variable: GDPCP

According to the model summary, the value of $\mathrm{R}$-squared resulted 0.444 which means that $44.40 \%$ of the variance of the dependent variable (i.e., total tax revenue) can be explained by the independent variable (i.e., tax evasion) and the rest of $66.60 \%$ can be explained by other variables (residuals) not included here. According to the model summary, the R-squared stood at $44.60 \%$, which is lower than the $60 \%$. Statistically, more than $60 \%$ is considered the nicely fitted to explain the dependent variable. Thus, the position is weak in this respect. Similarly, the value of Durbin-Watson test stood close to one, (i.e., 0.939) which positively auto-correlated (i.e., far from the data element). It means that, to some extent, the error terms are dependent on each other.

Similarly, in the following table, we produced the result of regression coefficient to discuss the influence of the tax evasion on the economic growth.

Table 7 Coefficients of the influence of the tax evasion on the GDP (current price)

\begin{tabular}{|c|c|c|c|c|c|c|c|c|}
\hline \multirow{2}{*}{\multicolumn{2}{|c|}{ Model }} & \multicolumn{2}{|c|}{$\begin{array}{c}\text { Unstandardized } \\
\text { Coefficients }\end{array}$} & \multirow{2}{*}{$\begin{array}{c}\begin{array}{c}\text { Standardized } \\
\text { Coefficients }\end{array} \\
\text { Beta }\end{array}$} & & \multirow[t]{2}{*}{ Sig. } & \multicolumn{2}{|c|}{$\begin{array}{l}95.0 \% \text { Confidence Interval } \\
\text { for B } \\
\end{array}$} \\
\hline & & $\mathrm{B}$ & Std. Error & & & & Lower Bound & Upper Bound \\
\hline & ) & 209502.926 & 26768.747 & & 1.020 & .000 & 146 & 272800.954 \\
\hline & TE & -147.440 & 62.412 & -.666 & -2.362 & .050 & -295.022 & .141 \\
\hline
\end{tabular}

a. Dependent Variable: GDPCP

According to the above table, the test of normality showed the significance level at $5 \%$ where the calculated value stood at the same percentage. As the result, there is a significant negative relationship between tax evasion and economic growth. The empirical result showed that, other things remaining the same, an increase in the value of tax evasion by 1-unit leads to a decrease in the value of economic growth (i.e., GDP) decreases by 147.440. Thus, considering only the p-value, the result suggested rejecting the null hypothesis.

\section{Discussion}

Tax evasion is a major devil of public finance, which seriously damages the public economic and its stability. Scholars have identified various negative effects of tax 
evasion in an economy. For example, Gillman and Kejak (2006) stated that no positive correlation between the tax evasion and the size of the underground, black or dirty economy exists. Similarly, some economists argue that to control the tax evasion is a difficult task. In this regard, Wan (2009) mentioned that governments face difficulties in monitoring the indirect taxes compared to direct taxes. In the case of Nigeria, John and Enoch (2013) claimed that the low quality of the service, tax system, the perception of fairness, low transparency and accountability of public institutions, and high level of corruption significantly influenced tax avoidance and evasion.

The evidence proves that mixed behaviour of the taxpayers. For example, the study of Erard and Feinstein (1994) proved that the traditional theory of underreporting the income is the behaviour of the taxpayers consequently they make the strategic tax reports, but empirical evidence suggests that many taxpayers are inherently honest and report truthful facts. However, some experts argue that the person who involve in corruption and tax evasion also maintain similar behaviour. For example, Tanzi (2017) defined corruption as "the act of breaking an accepted social or legal norm" (p. 2) and presented a list of factors which stimulate corruption and facilitate tax evasion, avoidance and corruption under a tax administration: (a) lack of efficiency and attendance, (b) lack of morale in workers, (c) level of salary, (d) low and inadequate salary, (e) structure of salary, (f) job tenure, (g) cultural facet of society of the job holders, (h) contagion of workers, (i) discrimination in actions, (j) relationship with politicians of the workers, (k) lack of incentives, (l) appointment of politically connected persons, and (m) corrupt and unethical policymakers.

Nepal is not exception to the tax cheating or evasion behaviour. The major compliance issues of Nepal are: (a) low registration in both income tax and VAT, (b) low return of filing (high percent of non-filers), (c) under invoicing and a huge percent of non-invoicing, (d) existence of large percent of the mismatch (difference in reporting among the transacted parties), (e) tax fraud (a large percentage exist in VAT with fake bill), (f) a huge amount of tax dues of many firm, (g) huge pending cases with Revenue Tribunal, and (h) negative attitude of politicians to make the good tax compliance environment.

Therefore, reduction of tax evasion is possible through the strong legal system. A leading scholar, Bird (2015) stressed on the need for a strong legal system, clear communication and stable law in order to reduce the tax evasion.

\section{Conclusion}

The phenomenon of tax evasion is probably as old as taxation itself. It is a pervasive disease not only in the economy of Nepal, but also in the entire economy of the world. Policymakers have been keeping their efforts perpetual to eradicate the disease of tax evasion. However, their efforts to keep it in check have been relatively unsuccessful so far. In this regard, Hasseldine and Bebbington (1991) opined, "There are no cures for many serious medical diseases likewise there are no solutions for the social disease of tax evasion" (p. 320).

In the study, we found a strong negative association between the variables (i.e., tax evasion and total tax revenue (-0.678) and tax evasion and economic growth $(-0.666))$ under correlation analysis. Similarly, a negative influence of the tax evasion on total tax revenue and economic growth under the regression analysis was found. The 
examination of the influence of tax evasion on the total tax revenue showed that, other elements of taxes remaining constant, an increase in the tax evasion by 1-unit leads to a decrease in the value of total tax revenue by 34.037. In the same way, study of the influence of the tax evasion on the economic growth (at current price) showed that an increase in tax evasion by 1-unit leads to a decrease in the value of economic growth by 147.440, other things remaining the same. Thus, the association and influence of tax evasion between and on the total tax revenue and economic growth were found in the negative (inverse) stance. Thus, the result suggested that rejecting the null hypothesis.

There is an acute problem of tax evasion in Nepal, it reduces not only the effectiveness of the government's operations, also reduces the prosperity of both the nation and its citizens. Several provisions in the income tax act leave room for dual meaning, which could lead to abuse. Therefore, Nepal should establish a less complex and more internationally competitive tax regime in order to reduce both tax evasion and corruption.

\section{Scope for further research}

This study concentrated only on the association between research variables (i.e., tax evasion, total tax revenue and economic growth) and the influence of the tax evasion on total tax revenue and economic growth observing the data from a period of nine years. However, chances are that results from the study would have been different had we observed data from a longer period. Thus, we suggest further research on this concept again based on long-term time series data.

\section{References}

Adebisi, J. F., \& Gbegi , D. O. (2013). Effect of tax avoidance and tax evasion on personal income tax administration in Nigeria. American Journal of Humanities and Social Sciences, I(3), 125-134. doi:10.11634/232907811301328

Ahmad, S., Sial, M. H., \& Ahmad, N. (2016). Taxes and economic growth: An empirical analysis of Pakistan. European Journal of Business and Social Sciences, V(2), 16-29.

Barth, E., Cappelen, A. W., \& Ognedal, T. (2006). Fair tax evasion. Oslo: University of Oslo.

Bekoe, W. (2012). Tax evasioin and economic growth in selected african countries, 1985-2010. Journal of Monetary and Economic Integration, XII(1), 34-67.

Bethencourt, C., \& Kunze, L. (2016). Tax evasion, social norms and economic growth. 3rd conference on the Shadow Economy, Tax Evasion and Governance (pp. 3-63). Muenster: Spanish Ministry of Science and Technology.

Bird, R. M. (2015). Improving tax administration in developing countries. Journal of Tax Administration, I(1), 23-45.

Burg, D. F. (2004). A world history of tax rebellions: An encyclopedia of tax rebels, revolts, and riots from antiquity to the present. New York: Routledge - An Imprint of Taylor \& Francis Books, Inc.

Dalu, T., Maposa, V. G., Pabwaungana, S., \& Dalu, T. (2012). The impact of tax evasion and avoidance on the economy: a case of Harare, Zimbabwe. African J. Economic and Sustainable Development, I(3), 284-296.

Devos, K. (2005). The attitudes of tertiary students on tax evasion and the penalties for tax evasion: A pilot study and demographic analysis. eJournal of tax research, III(2), 222-273.

Erard, B., \& Feinstein, J. S. (1994). Honesty and evasion in the tax compliance game. The RAND Journal of Economics, XXV(1), 1-19. 


\section{Pravaha Journal-2018}

Friedland, N., Maital, S., \& Rutenberg, A. (1978). A simulation study of income tax evasion. Journal of Public Economics, X, 107-116.

Gillman, M., \& Kejak, M. (2006). Accounting for corruption: Taxes, the shadow economy, endogenous growth and inflation. Prague: CERGE-El.

Gillman, M., \& Kejak, M. (n.d.). Accounting for corruption: The effect of tax evasion and inflation on growth. Econometrics Conference at Brunel University (pp. 1-76). Prague: Econometrics Conference at Brunel University.

Gyawali, K. (2017, April 15). Kara pharchhyot bhandai 21 arba loot. Retrieved from eKantipur: http://kantipur.ekantipur.com/news/2017-04-15/20170415072820.html

Hasseldine, J. D., \& Bebbington, J. K. (1991). Blending economic deterrence and fiscal psychology models in the design of responses to tax evasion: The New Zealand experience. Journal of Economic Psychology, XII, 299-324.

Inland Revenue Department . (2008-2016). Annual Reports. Kathmandu: Inland Revenue Department.

John, A. O., \& Enoch, O. K. (2013). Appraisal of factors influencing tax avoidance and evasion in Nigeria. International Journal of Research in Commerce and Management, IV(5), 107-111.

Joulfaian, D. (2009). Bribes and business tax evasion. The European Journal of Comparative Economics, $\mathrm{VI}(2), 227-244$.

Malkawi, B. H., \& Haloush, H. A. (2008). The case of income tax evasion in Jordan: symptoms and solutions. Journal of Financial Crime, XV(3), 282-294.

McCann, H. (2006). Offshore finance. Cambridge: Cambridge University Press.

McCulloch, J. R. (1863). A treatish on the principles and practical influence of taxation and the funding system. Edingurgh: Adam and Charles Black.

Mehrara, M., \& Farahani, Y. G. (2016). The study of the effects of tax evasion and tax revenues on economic stabilities in OECD countries. World Scientific News, XXXIII, 43-55.

Mehrara, M., \& Farahani, Y. G. (2016). The study of the effects of tax evasion and tax revenues on economic stabilities in OECD countries. World Scientific News(33), 43-55.

Murray, M. N. (1997). Would tax evasion and tax avoidance undermine a national retail sales tax? National Tax Journal, L(1), 167-182.

Nalishebo, S., \& Halwampa, A. (2014). Uncovering the unknown: An analysis of tax evasion in Zambia. Zambia: Zambia Institute for Policy Analysis \& Research.

Nepali Times. (2002, February 1-7). Tax evasion is a part of Nepali culture, 79. Retrieved June 5, 2017, from Nepali Times: http://nepalitimes.com/news.php?id=6342\#.WTW_DdwIHIW

Sharma, P., \& Dang, S. (2011). Myth and reality of the imbricating concepts of tax avoidance and evasion. Journal of Accounting and Taxation, III(3), 40-46.

Simser, J. (2008). Tax evasion and avoidance typologies. Journal of Money Laundering Control, XI(2), 123-134. doi:10.1108/13685200810867456

Slemrod, J. (2007). Cheating ourselves: The economics of tax evasion. Journal of Economic Perspectives, XXI(1), 25-48.

Tabandeh, R., Jusoh, M., Nor, N. M., \& Zaidi, M. S. (2012). Estimating factors affecting tax evasion in Malaysia: A neural network method analysis. Prosiding Perkem, VII(2), 1524 - 1535.

Tanzi, V. (2017). Corruption, complexity and tax evasion. Tax and Corruption Symposium (pp. 1-25). Sidney: UNSW Business School.

The Kathmandu Post. (2017, January 25). Nepal ranks 131 in corruption perception index. Retrieved from The Kathmandu Post: http://kathmandupost.ekantipur.com/news/2017-01-25/nepalranks-131-of-176-nations-in-transparency-internationals-corruption-index.html 
The World Bank. (2016, October 25). Nepal slips in ease of doing business ranking: World Bank. Retrieved from The World Bank, IBRD-IDA: http://www.worldbank.org/en/news/pressrelease/2016/10/25/Nepal-slips-in-ease-of-doing-business

Trading Economics. (2017, June 5). Nepal corruption rank. Retrieved from Trading Economics: https://tradingeconomics.com/nepal/corruption-rank

Uadiale, O. M., Fagbemi, T. O., \& Ogunleye, J. O. (2010). An empirical study of the relationship between culture and personal income tax evasion in Nigeria. European Journal of Economics, Finance and Administrative Sciences, 20, 116-126.

Wan, J. (2009). A solution to tax evasion. Fukuoka: Center for Advanced Economic Study Fukuoka University.

Xuereb, A. (2015). Tax avoidance or tax evasion? Symposia Miletensia, X, 217-229.

Z. Z., Simonovits, A., \& Vincze, J. (2012). Tax morale and tax evasion: Social preferences and bounded rationality. Economic Analysis \& Policy, XXXXII(2), 171-188. 